\title{
Characterization and mechanisms of anti- influenza virus metabolites isolated from the Vietnamese medicinal plant Polygonum chinense
}

Thu Thi Tran ${ }^{1 \dagger}$, Meehyein Kim² ${ }^{2 \dagger}$, Yejin Jang ${ }^{2}$, Hye Won Lee ${ }^{2}$, Hoa Thi Nguyen ${ }^{1,3}$, Thanh Ngoc Nguyen 4 , Hae Woong Park, Quang Le Dang ${ }^{1 *}$ and Jin-Cheol Kim ${ }^{3^{*}}$ (D)

\begin{abstract}
Background: Polygonum chinense Linn. is a common medicinal plant in Southeast Asia and has been used in traditional medicine in Vietnam. The plant contains phytochemicals with various biological properties; however, its antiviral effect has not yet been demonstrated. This study was aimed to evaluate the anti-influenza virus activity of crude extracts of $P$. chinense, to characterize antiviral metabolites therefrom and to investigate their mechanisms of antiviral action.

Methods: The methanol (MeOH) extract and organic solvent layers of $P$. chinense were prepared by extraction and partition with relevant solvents. The ethyl acetate (EtOAc) layer showing antiviral activity was chromatographed repeatedly on $\mathrm{SiO}_{2}$ and Sephadex LH-20 columns to give eight pure metabolites. Their chemical structures were determined by NMR and MS spectral data. Anti-influenza virus activity of the eight metabolites against virus strains A/Puerto Rico/8/34 (H1N1, PR8), A/Hong Kong/8/68 (H3N2, HK) and B/Lee/40 (Lee) was evaluated on the basis of cytopathic effect (CPE) and plaque inhibition assays. Time-of-addition, confocal microscopy and neuraminidase inhibition assay were performed for mode-of-action studies of active ingredients.
\end{abstract}

Results: The $\mathrm{MeOH}$ extract of $P$. chinense showed anti-influenza virus activity with $\mathrm{EC}_{50}$ values ranging from 38.4 to $55.5 \mathrm{\mu g} / \mathrm{mL}$ in a CPE inhibition assay. Among the eight pure metabolites isolated from P. chinense, ellagic acid (PC5) , methyl gallate (PC7) and caffeic acid (PC8) significantly inhibited viral replication in a dose-dependent manner in both plaque inhibition and CPE inhibition assays with $\mathrm{EC}_{50}$ values ranging from 14.7 to $81.1 \mu \mathrm{g} / \mathrm{mL}$ and $\mathrm{CC}_{50}$ values higher than $300 \mathrm{\mu g} / \mathrm{mL}$. Mode-of-action studies suggested that PC5 and PC7 suppress virus entry into or replication in cells, while PC8 targets influenza viral neuraminidase, even oseltamivir-resistant one.

Conclusion: These results demonstrated that $P$. chinense and its metabolites possess effective anti-influenza virus activities. The botanical materials of $P$. chinense could be a promising multitargeted inhibitor of influenza $A$ and $B$ viruses and applied to development of a novel herbal medicine.

Keywords: Antiviral, Influenza virus, Polygonum chinense, Ellagic acid, Methyl gallate, Caffeic acid

\footnotetext{
*Correspondence: ledangquang2011@gmail.com; kjinc@jnu.ac.kr

${ }^{\dagger}$ Equal contributors

${ }^{1}$ R\&D Center of Bioactive Compounds, Vietnam Institute of Industrial

Chemistry, 2nd Pham Ngu Lao, Hoan Kiem, Hanoi 10 000, Vietnam

${ }^{3}$ Department of Agricultural Chemistry, Institute of Environmentally Friendly

Agriculture, College of Agriculture and Life Sciences, Chonnam National

University, 77 Yongbong-Ro, Buk-Gu, Gwangju 500-757, Republic of Korea

Full list of author information is available at the end of the article
} 


\section{Background}

Influenza virus is an enveloped virus with negativestrand, eight-segmented RNA genomes, belonging to the Orthomyxoviridae family. Each viral segment is encapsidated by a virus-encoded nucleoprotein (NP), called viral ribonucleoprotein (vRNP) [1]. Influenza virions are pleomorphic, roughly spheroidal and approximately $100 \mathrm{~nm}$ in diameter [2]. The viral envelope is distinguished by a lipid bilayer containing three transmembrane protein$\mathrm{s}$-hemagglutinin (HA), neuraminidase (NA), and matrix protein 2 (M2, ion channel) on the outside and matrix protein 1 (M1) beneath the membrane. The virus causes pandemics and annual influenza epidemics. Influenza outbreaks result in morbidity and mortality in the human population and commonly occur during winter, or the rainy season in tropical countries [3, 4].

Pharmaceutical ingredients can be classified into two groups: NA inhibitors, such as oseltamivir and zanamivir, and M2 inhibitors, such as amantadine and rimantadine. These have been approved and used to treat and prevent influenza infections. The NA inhibitors are effective against both influenza A and B viruses, while the M2 inhibitors are effective only against influenza A virus [5]. However, long-term use of these drugs is limited by their toxicity and emergence of resistance [6]. Therefore, the development of new, low-toxic anti-influenza viral drugs is required.

Polygonum chinense ( $P$. chinense) Linn. belonging to the family Polygonaceae is a common medicinal plant found in China, India, Japan and Southeast Asian countries. In Vietnam, the plant is widespread nationwide, especially in open forest and highland [7]. This plant has been used in traditional medicine for skin infectious diseases such as eczema and zona, indigestion, gastroenteritis and hepatitis, as well as for healing inflammatory wounds or insect stings and snakebites $[7,8]$. Several phytochemistry studies of $P$. chinense have been revealed that the plant contains terpenoids, alkaloids, flavonoids, tannins, steroids and glycosides [8-10]. Aqueous leaf extract of P. chinense possesses gastroprotective activity [11]. Its methanol $(\mathrm{MeOH})$ extract showed antimicrobial, antioxidant and cytotoxic activities in vitro [8, 12]. Ethanol extract and isolated bioactive substances exerted antidiarrheal effects [13]. However, its antiviral potential has not been investigated. During screening of plant extracts against influenza viruses, we found that the methanol extract of $P$. chinense exhibited antiviral activity. Therefore, the objectives of this study were to examine the antiviral activities of its crude extracts against influenza virus strains A/Puerto Rico/8/34 (H1N1, PR8), A/Hong Kong/8/68 (H3N2, HK) and B/Lee/40 (Lee), to isolate and identify effective metabolites and to investigate their mechanisms of action.

\section{Methods}

\section{Chemicals and reagents.}

Silica gel $60 \AA$ grade (particle sizes $15-40 \mu \mathrm{m}$ and 40 $63 \mu \mathrm{m})$ for column chromatography was purchased from Merck (Darmstadt, Germany). Sephadex LH-20 beads (size 25-100 $\mu \mathrm{m}$ ) were purchased from SigmaAldrich (St Louis, MO). Thin-layer chromatography (TLC) plates (silica gel 60 F254, thickness $0.2 \mathrm{~mm}$ ) were obtained from Merck. Chemical spots on TLC plates after development were detected using $p$-anisaldehyde-sulfuric acid (AS) and ferric chloride staining reagents, together with $I_{2}$ vapor. All solvents were distillated and purified before use.

\section{Plant material}

$P$. chinense samples were collected at Nhu Xuan in Thanh Hoa province, Vietnam. Whole plant was dried in the darkness and ground before extraction. Plant species were identified by Dr. Tran The Bach (Institute of Ecology and Biological Resources, Vietnam). A voucher specimen of the plant (No TL-CNHD.ĐT.048/13-15) was deposited in the R\&D Center of Bioactive Compounds, Vietnam Institute of Industrial Chemistry, Vietnam.

\section{Extract preparation and isolation of pure compounds}

Dried and powdered $P$. chinense $(10 \mathrm{~kg})$ was extracted with $\mathrm{MeOH}$ at room temperature and concentrated to dryness in a rotary evaporator under reduced pressure at below $40{ }^{\circ} \mathrm{C}$. The $\mathrm{MeOH}$ extract (224 g) was suspended in $2 \mathrm{~L}$ of distillated water and consecutively partitioned with equal volumes of ethyl acetate (EtOAc) and butanol $(\mathrm{BuOH})$.

The EtOAc layer (95.2 g) was separated on a Sephadex LH-20 (130 g, 70-100 $\mu \mathrm{m}$, Sigma-Aldrich; $3.0 \mathrm{~cm} \times 70 \mathrm{~cm}$ ) with $\mathrm{MeOH}$ eluent. The fractions that showed similar TLC patterns were combined to yield more homogenous samples, Frs. 1 to 9. Fr. 2 (13.6 g) which contains a main component at $\mathrm{R}_{\mathrm{f}} 0.83$ on TLC (developed with EtOAc:$\mathrm{MeOH}$ 20:1 and showing a positive reaction with ferric chloride stain) was separated on a silica gel column [146 g silica gel $60 \AA(40-63 \mu \mathrm{m}), 3.4 \times 40 \mathrm{~cm}$ ] and was eluted with a dichloromethane (DCM)-acetone stepwise gradient (100: 1 to 100\% acetone), yielding additional 12 fractions, Frs. 21 to 212 . Fr. 26 contained a main compound and was crystalized with acetone to give crystals of PC1. Fr. $3(7.2 \mathrm{~g})$ was applied to a $\mathrm{SiO}_{2}$ column [142 g silica gel $60 \AA(40-63 \mu \mathrm{m}), 3.4 \times 40 \mathrm{~cm}$, packed with $\mathrm{H}$ :EtOAc $(5: 5, v / \mathrm{v})]$ and was eluted with a nHexane $(\mathrm{H})$ : EtOAc stepwise gradient (5:5 to $1: 9$ and EtOAc: $\mathrm{MeOH}$ 20:1 v/v, $500 \mathrm{~mL}$ each step) to produce five fractions, Frs. 31 to 35. Fr. 33 was further chromatographed on a silica gel column $\left[\mathrm{SiO}_{2} 60 \AA(15-40 \mu \mathrm{m})\right.$, $2.0 \times 45 \mathrm{~cm}$ ] using DCM:MeOH $(9: 1, v / \mathrm{v})$ to give Fr. 34, which contained crystals of compound PC3. Compound 
PC4 was isolated from Fr. 35 by chromatography using silica gel [63 g, silica gel $60 \AA(40-63 \mu \mathrm{m}), 2.0 \times 50 \mathrm{~cm}$ ] and eluting with a $\mathrm{H}$ :EtOAc stepwise gradient $(7: 3$ to 1:9, v/v) and mixtures of EtOAc:MeOH (50:1, 30:1, 20:1 and $8: 2,7: 3, v / \mathrm{v}, 150 \mathrm{~mL}$ each step). Fr. 31 was also isolated using a silica gel column $\left[\mathrm{SiO}_{2} 60 \AA\right.$ (15$40 \mu \mathrm{m}), 2.0 \times 45 \mathrm{~cm}$ ] with a stepwise gradient elution of $\mathrm{H}:$ EtOAc (10:1 to $3: 7 ; 10 \%$ gradient and $100 \%$ EtOAc), yielding compound PC7. A portion of Fr. 4 (1.23 g) was subjected to column chromatography using a silica gel column [37 $\mathrm{g} \mathrm{SiO}_{2} 60 \AA(40-63 \mu \mathrm{m}), 3.0 \times 45 \mathrm{~cm}$ ] with eluting solvents of EtOAc: acetone $(10: 1, v / \mathrm{v}, 200 \mathrm{~mL})$ and DCM:MeOH $(20: 1, v / v, 400 \mathrm{~mL})$, yielding three fractions, Frs. 41 to 43. PC2 was crystallized from the third fraction, Fr. 43. Fr. 6 (20 g) was applied to a Sephadex LH-20 column [100 g, 70-100 $\mu \mathrm{m}$, Sigma-Aldrich; $2.2 \times 60 \mathrm{~cm}]$ and eluted with $\mathrm{MeOH}$ to give five fractions, Frs. 61-65. Fr. 63 was chromatographed using silica gel and mixtures of E:MeOH (30: and 25:1) to furnish PC8. Compound PC5 was purified from Fr. 5 (4 g) using a Sep-pak C18 reverse-phase column and elution with a water- $\mathrm{MeOH}$ mixture with a $\mathrm{MeOH}$ proportion increasing from 70:30 to $100 \% \mathrm{MeOH}$.

A portion of Fr.1 (9.8 g) was separated on a silica gel [100 g silica gel $60 \AA(40-63 \mu \mathrm{m}), 4.0 \times 45 \mathrm{~cm}$ ] column and eluted using mixtures of $\mathrm{H}$ :acetone $(98: 2 ; 500 \mathrm{~mL})$ and DCM:MeOH $(95: 5 ; 400 \mathrm{~mL})$ to give seven fractions, Frs. 11 to 17. Frs. 13 and 14, which exhibited similar TLC patterns, were pooled into Fr. 134 (2.6 g) and then chromatographed on a silica gel column [70 g silica gel $60 \AA(40-63 \mu \mathrm{m}), 3.0 \times 45 \mathrm{~cm}]$ with a mixture of $\mathrm{H}$ :acetone (8:2), yielding compound PC6.

\section{Structure determination and characterization of the isolated compounds}

The chemical structures were determined by spectroscopic methods, including electrospray ionization (ESI)mass spectroscopy (MS) and nuclear magnetic resonance (NMR) spectroscopy, and by comparison of their spectral data with values reported previously $[12,16]$. The ESI-MS spectra of the purified compounds were recorded by LCMS (Agilent 1100 Series LC/MSD Trap XCT Plus, Agilent Technologies, Palo Alto, CA). The ${ }^{1} \mathrm{H}$ and ${ }^{13} \mathrm{C}$ NMR, COSY, HMQC and HMBC spectra were recorded in deuterated NMR solvents using a Bruker AMX-500 FT-NMR spectrometer (Bruker Analytische Messtechnik Gmbh, Rheinstetten, Germany).

PC1 (Quercetin): ESI-MS (positive) $(\mathrm{m} / z) 303[\mathrm{M}+\mathrm{H}]^{+}$, ${ }^{1} \mathrm{H}-\mathrm{NMR}\left(500 \mathrm{MHz}, \mathrm{DMSO}-d_{6}\right), \delta$ (ppm): $6.183(1 \mathrm{H}, \mathrm{d}$, $J=2.0 \mathrm{~Hz}, \mathrm{H}-6), 6.403(1 \mathrm{H}, \mathrm{d}, J=2.0 \mathrm{~Hz}, \mathrm{H}-8), 6.88(1 \mathrm{H}, \mathrm{d}$, $\left.J=8.5 \mathrm{~Hz}, \mathrm{H}-5^{\prime}\right), 7.535\left(1 \mathrm{H}, \mathrm{dd}, J=2.5,8.5 \mathrm{~Hz}, \mathrm{H}-8^{\prime}\right), 7.67$ $\left(1 \mathrm{H}, \mathrm{d}, J=2.0 \mathrm{~Hz}, \mathrm{H}-2^{\prime}\right) ;{ }^{13} \mathrm{C}-\mathrm{NMR}(125 \mathrm{MHz}, \mathrm{DMSO}-$ $\left.d_{6}\right), \quad \delta(\mathrm{ppm}): 93.308$ (C8), 98.138(C6), 102.976 (C10), 115.028(C2'), 116.2 (C5'), 119.938 (C6'), 121.917(C1'),
135.683 (C3), 145.016 (C3'), 146.774 (C2), 147.662 (C4'), 156.098 (C9), 160.682 (C5), 163.837 (C7), 175.8 (C4).

PC2 (Protocatechuic acid methyl ester): ESI-MS (negative) $(\mathrm{m} / z) 167.01[\mathrm{M}-\mathrm{H}]^{-},{ }^{1} \mathrm{H}-\mathrm{NMR}(500 \mathrm{MHz}$, acetone$\left.d_{6}\right), \delta$ (ppm): $3.801\left(3 \mathrm{H}, \mathrm{s},-\mathrm{OCH}_{3}\right), 6.893(1 \mathrm{H}, \mathrm{d}$, $J=8.5 \mathrm{~Hz}, \mathrm{H}-5) ; 7.435$ (1H, dd, $J=2.0,8.5 \mathrm{~Hz}, \mathrm{H}-2), 7.493$ $(1 \mathrm{H}, \mathrm{d}, J=2.0 \mathrm{~Hz}, \mathrm{H}-6) ;{ }^{13} \mathrm{C}-\mathrm{NMR}\left(125 \mathrm{MHz}\right.$, acetone- $\left.d_{6}\right)$, $\delta$ (ppm): $51.84\left(-\mathrm{OCH}_{3}\right), 115.74$ (C2), 117.14 (C5), 122.83 (C1), 123.26 (C6), 145.62 (C3), 150.77 (C4), 167.07 (으).

PC3 (Gallic acid): ESI-MS (positive) $(\mathrm{m} / \mathrm{z}) \quad 339.0$ $[2 \mathrm{M}-\mathrm{H}]^{-}, 193[\mathrm{M}+\mathrm{Na}]^{+} ;{ }^{1} \mathrm{H}-\mathrm{NMR}(500 \mathrm{MHz}$, $\left.\mathrm{CD}_{3} \mathrm{OD}-d_{4}\right), \delta$ (ppm): 7.076 (2H, s, H-2,6); ${ }^{13} \mathrm{C}-\mathrm{NMR}$ $\left(125 \mathrm{MHz}, \mathrm{CD}_{3} \mathrm{OD}-d_{4}\right), \delta$ (ppm): $110.32(\mathrm{C} 2,6), 122.02$ (C1), 139.33 (C4), 146.38 (C3, 5), 170.49 (COOH).

PC4 (Quercitrin): The compound was identified as quercetin 3-O-rhamnoside (also known as quercitrin) by comparison with an authentic sample $\left(R_{f} 0.54\right)$ on a TLC plate using an E:A:M (40: 1:1, v/v/v) developing solvent and detected using the appropriate stains: AS and ferric chloride.

PC5 (Ellagic acid): ESI-MS (positive) $(m / z) 325[\mathrm{M}+\mathrm{Na}]^{+}$, ESI-MS (negative) $m / z 301[\mathrm{M}-\mathrm{H}]^{-},{ }^{1} \mathrm{H}-\mathrm{NMR}(125 \mathrm{MHz}$, DMSO- $\left.d_{6}\right), \delta$ (ppm): 2.08-4.5 (s, $\left.-\mathrm{OH}\right) ; 7.483(2 \mathrm{H}, \mathrm{s}, \mathrm{H}-$ $\left.5,5^{\prime}\right) ;{ }^{13} \mathrm{C}-\mathrm{NMR}\left(500 \mathrm{MHz}, \mathrm{DMSO}-d_{6}\right), \delta$ (ppm): 107.470 (C1,1'), $110.200\left(\mathrm{C} 5,5^{\prime}\right), 112.072\left(\mathrm{C} 6,6^{\prime}\right), 136.274\left(\mathrm{C} 2,2^{\prime}\right)$, 139.377 (C3, 3'), 147.920 (C4, 4'), 158.728 (C7, 7').

PC6 ( $\beta$-Sitosterol): ${ }^{1} \mathrm{H}-\mathrm{NMR}\left(500 \mathrm{MHz}, \mathrm{CDC}_{3}-d\right), \delta$ (ppm): 0.69 (3H, s, H-18), $0.803(3 \mathrm{H}, \mathrm{d}, J=6.0 \mathrm{~Hz}, \mathrm{H}-$ 27), $0.826(3 \mathrm{H}, \mathrm{d}, J=4.0 \mathrm{~Hz}, \mathrm{H}-26), 0.845(3 \mathrm{H}, \mathrm{t}$, $J=2.0 \mathrm{~Hz}, \mathrm{H}-29), 0.925$ (3H, d, $J=4.0 \mathrm{~Hz}, \mathrm{H}-21), 1.008$ (3H, s, H-19), 2.282-1.071 (28H, m), 2.305 (2H, m), 3.486 (1H, m, H-3), 5.347 (1H, brs, H-6); ${ }^{13} \mathrm{C}-\mathrm{NMR}$ (125 MHz, $\left.\mathrm{CDC1}_{3}-d\right), \delta$ (ppm): 11.989 (C29), 12.215 (C24), 18.918 (C28), 19.180 (C19), 19.523 (C27), 19.945 (C26), 21.222 (C11), 23.215 (C23), 26.251 (C21), 28.376 (C16), 29.313 (C25), 31.779 (C2), 32.049 (C7), 32.049 (C8), 34.095 (C20), 36.279 (C18), 36.642(C10), 37.401 (C1), 39.923 (C12), 42.423 (C4), 42.460 (C13), 45.985 (C22), 50.286 (C9), 56.212 (C17), 56.911 (C14), 56.911 (C15), 71.908(C3), 121.817 (C6), 140.908(C5).

PC7 (Methyl gallate): ESI-MS (positive) $\mathrm{m} / z \quad 185$ $[\mathrm{M}+\mathrm{H}]^{+},{ }^{1} \mathrm{H}-\mathrm{NMR}\left(500 \mathrm{MHz}, \mathrm{CD}_{3} \mathrm{OD}-d_{6}\right), \delta$ (ppm): $3.825\left(3 \mathrm{H}, \mathrm{s},-\mathrm{OCH}_{3}\right) ; 7.067(2 \mathrm{H}, \mathrm{s}, \mathrm{H}-2,6) ;{ }^{13} \mathrm{C}-\mathrm{NMR}$ $\left(125 \mathrm{MHz}, \mathrm{CD}_{3} \mathrm{OD}-d_{6}\right), \delta(\mathrm{ppm}): 52.250 \quad\left(-\mathrm{OCH}_{3}\right)$; 110.044 (C2, 6), 121.449 (C1), 139.703 (C4), $14 \overline{6} .441$ (C3, 5), 169.007 (COO).

PC8 (Caffeic acid): ${ }^{1} \mathrm{H}-\mathrm{NMR}\left(500 \mathrm{MHz}, \mathrm{CD}_{3} \mathrm{OD}-d_{4}\right)$, $\delta$ (ppm): $6.24(1 \mathrm{H}, \mathrm{d}, J=16 \mathrm{~Hz}, \mathrm{H}-8), 6.80(1 \mathrm{H}, \mathrm{d}$, $J=8.5 \mathrm{~Hz}, \mathrm{H}-5), 6.94(1 \mathrm{H}, \mathrm{dd}, J=10.5 \mathrm{~Hz}, J=2.0 \mathrm{~Hz}$, $\mathrm{H}-6), 7.06(1 \mathrm{H}, \mathrm{d}, J=2.0 \mathrm{~Hz}, \mathrm{H}-2), 7.55(1 \mathrm{H}, \mathrm{d}$, $J=15.5 \mathrm{~Hz}, \mathrm{H}-7) ;{ }^{13} \mathrm{C}-\mathrm{NMR}\left(125 \mathrm{MHz}, \mathrm{CD}_{3} \mathrm{OD}-d_{4}\right), \delta$ (ppm): 115.104 (C2), 115.513 (C8), 116.488 (C5), 122.840 (C6), 127.803 (C1), 146.763 (C3), 147.038 (C7), 149.418 (C4), 171.022 (ㄷOH). 


\section{Cells, viruses and antiviral agents}

Madin-Darby canine kidney (MDCK) cells and 293 T cells were purchased from ATCC (Rockville, MD) and maintained in minimum essential medium (MEM; Invitrogen, Carlsbad, CA) and in Dulbecco's minimal essential medium (DMEM; Invitrogen), respectively, supplemented with $10 \%$ fetal bovine serum (FBS; Invitrogen) at $37{ }^{\circ} \mathrm{C}$ in $5 \% \mathrm{CO}_{2}$. Influenza viruses PR8, $\mathrm{HK}$ and Lee were obtained from ATCC. Influenza A viral strains (PR8 and HK) were amplified by infection of 10 -day-old chicken eggs at $37^{\circ} \mathrm{C}$ for 3 days and influenza $B$ virus (Lee) by infection of MDCK cells under serum-free conditions. Viruses were partially purified from harvested egg allantoic fluid or cell culture supernatant by centrifugation at $3000 \mathrm{rpm}$ for $5 \mathrm{~min}$. Viral titers were determined by $\mathrm{HA}$ assay or plaque assay, and stocks were stored at $-70{ }^{\circ} \mathrm{C}$ before use. Antiviral agents, ribavirin (RBV) (Sigma-Aldrich) and oseltamivir carboxylate (OSV-C; US Biological, Swampscott, MA) were used as control compounds. The test extracts and purified compounds, with the exception of the water layer which was dissolved in water, were dissolved in DMSO to $40 \mathrm{mg} / \mathrm{mL}$ and stored at $-20{ }^{\circ} \mathrm{C}$.

\section{Rescue of PR8 virus with the H275Y mutation in NA}

DNAs derived from eight-segmented PR8 genomic RNAs were individually cloned into a vector harboring convergent RNA polymerase I and II promoters using a universal primer and genome-specific primers, generating $\mathrm{PVP}-\mathrm{PB} 2$, -PB1, -PA, -HA, -NP, -NA, -M and -NS [17-19]. Their sequences were compared to those in GenBank (accession numbers AB671295 for PB2, KC866596.1 for PB1, KC 866595.1 for PA, AB671289.1 for HA, KC866598.1 for NP, CY033579.1 for NA, EF467824.1 for M and EF467817 for NS, respectively). Using the plasmid pVP-NA, a histidinto-tyrosin mutation at amino acid 275 (H275Y) was introduced with a primer (5'-GAATGCACCTAATTTTTACT ACGAGGAATGTTC-3': sequences corresponding to the mutant tyrosin in bold) and its complementary one. The QuickChange II Site-Directed Mutagenesis Kit (Stratagene, LA Jolla, CA) were used to generate pVP-NA(H275Y). For production of $\mathrm{PR} 8$ virus with the NA mutation $\mathrm{H} 275 \mathrm{Y}$ [rgPR8(H275Y)] by a reverse genetics system, $293 \mathrm{~T}$ cells were co-trasfected with pVP-NA(H275Y) and the rest seven $\mathrm{pVP}$ plasmids [17]. The rescued virus from the culture supernatants was propagated into embryonated chicken eggs and viral titer was determined as mentioned above.

\section{Cytopathic effect (CPE) inhibition assay}

Cell viability was measured according to our previous report [20]. In brief, MDCK cells were seeded in 96-well plates and grown until 100\% confluence. Cells were mock-infected or infected with influenza virus at a multiplicity of infection (MOI) of 0.001 for $1 \mathrm{~h}$ at $35{ }^{\circ} \mathrm{C}$ under serum-free conditions. Unabsorbed virus was removed by washing with $\mathrm{PBS}$, and threefold serial dilutions of compounds dissolved in MEM with $2 \mu \mathrm{g} /$ $\mathrm{mL}$ TPCK-trypsin were added to each well. On day 3 postinfection (p.i.), cell viability was measured using 3(4,5-dimethylthiazol-2-yl)-2,5-diphenyltetrazolium bromide (MTT; Sigma-Aldrich). After reading the absorbance at $540 / 690 \mathrm{~nm}$, the half maximal cytotoxic concentration $\left(\mathrm{CC}_{50}\right)$ and the half maximal effective concentration $\left(\mathrm{EC}_{50}\right)$ were calculated using GraphPad Prism 6 (GraphPad Software, La Jolla, CA). The selectivity index (S.I.) is the ratio of $\mathrm{CC}_{50}$ to $\mathrm{EC}_{50}$.

\section{Plaque inhibition assay}

MDCK cells seeded in 48-well plates were infected with the influenza viruses at an MOI of 0.001 for $1 \mathrm{~h}$ at $33{ }^{\circ} \mathrm{C}$ (PR8) or $35^{\circ} \mathrm{C}$ (HK and Lee). Test compounds and reference antiviral compounds were serially diluted in overlay medium [MEM containing $0.5 \%$ carboxymethylcellulose (CMC; Sigma) and $2 \mu \mathrm{g} / \mathrm{mL}$ TPCK-trypsin]. After washing with PBS, the cells were treated with the compounds in the overlay medium for 3 days at the temperature used for virus infection. Viral plaques were counted by staining with crystal violet $[20]$.

\section{Time-of-addition}

To determine when the purified materials, PC5, PC7 and PC8, express their anti-influenza viral activity, MDCK cells were treated with increasing concentrations (from 4 to $100 \mu \mathrm{M}$ ) of each compound for $2 \mathrm{~h}$ before (pre-treatment), during (co-treatment) or after (posttreatment) PR8 infection [40 plaque forming units (PFU) per well in 48 -well plates] at $37{ }^{\circ} \mathrm{C}$. After washing with PBS, cells were incubated with overlay medium for 3 days at $33{ }^{\circ} \mathrm{C}$ and stained with crystal violet to count the number of viral plaques.

\section{Confocal microscopy}

Confluently grown MDCK cells in 4-well slides were infected with the influenza viruses at an MOI of 1 for $4 \mathrm{~h}$ in the presence either of $1 \mathrm{mM}$ PC5, PC7 or PC8, or of $10 \mu \mathrm{M}$ epigallocatechin gallate (EGCG), which was used as a control to block viral entry [19]. After fixation and permeabilization, cells were blocked with $10 \%$ goat serum and $1 \%$ bovine serum albumin (BSA; Sigma-Aldrich) in PBS. Viral NP was detected with mouse anti-NP antibody (Santa Cruz Biotechnology, Santa Cruz, CA) and Alex Fluor 488-conjugated goat anti-mouse IgG (Invitrogen). Nuclei were stained with DAPI (Vector Laboratories, Burlingame, CA) according to the manufacturer's instructions. 


\section{NA inhibition assay}

Twenty-five microliters of PR8 or $\operatorname{rgPR} 8(\mathrm{H} 275 \mathrm{Y})$ $\left(2 \times 10^{5} \mathrm{PFU} / \mathrm{mL}\right)$ in PBS were mixed with an equal volume of 3-fold serially diluted PC5, PC7, PC8 (from $6 \mathrm{mM}$ to $80 \mu \mathrm{M}$ ) or OSV-C (from 60 to $0.8 \mathrm{nM}$ ) in PBS in 96-well plates. After addition of $50 \mu \mathrm{L} 200 \mu \mathrm{M}$ NAfluor fluorescent substrate (Applied Biosystems, Foster City, CA), the reaction was incubated at $37^{\circ} \mathrm{C}$ for $1 \mathrm{~h}$ and stopped with $100 \mu \mathrm{L}$ of stop solution. The fluorescent intensity was measured with excitation at $350 \mathrm{~nm}$ and emission at $450 \mathrm{~nm}$.

\section{Statistical analysis}

Statistically significant differences were determined using two-tailed Student's $t$-test. $P<0.05$ was considered significant.

\section{Results and discussion}

Screening of antiviral activities in extracts from $P$. chinense The anti-influenza viral activity of $\mathrm{MeOH}$ extract and organic solvent layers from $P$. chinense was evaluated by $\mathrm{CPE}$ inhibition assay. Cell viability was measured using MTT to estimate the $\mathrm{CC}_{50}$ and $\mathrm{EC}_{50}$ values before and after infection of MDCK cells with PR8, HK and Lee (Table 1). As expected, OSV-C (an NA inhibitor) and RBV (a viral polymerase inhibitor) efficiently inhibited the replication of all viral strains tested, confirming the reliability of the assay. $\mathrm{MeOH}$ extract of $P$. chinense showed moderate inhibition of influenza viruses: $\mathrm{EC}_{50}$ values were $55.0 \mu \mathrm{g} / \mathrm{mL}$ for PR8, $38.8 \mu \mathrm{g} / \mathrm{mL}$ for $\mathrm{HK}$ and $55.5 \mu \mathrm{g} / \mathrm{mL}$ for Lee. The EtOAc layer derived from the $\mathrm{MeOH}$ extract by liquid-liquid partitioning exhibited $\mathrm{EC}_{50}$ values of $46.9,23.2$ and $50.8 \mu \mathrm{m} / \mathrm{mL}$, respectively. Moreover, the $\mathrm{MeOH}$ extract and EtOAc layer were not cytotoxic to MDCK cells at the highest concentration used, $300.0 \mu \mathrm{g} / \mathrm{mL}$. The $\mathrm{BuOH}$ layer also displayed antiviral efficacy similar to EtOAc layer. However, the aqueous layer showed limited or no activity.
Isolation and identification of substances from $P$. chinense Using repeated chromatographic processes, eight substances, PC1 to PC8, were further isolated from the EtOAc layer (Fig. 1). Compound PC1 was purified as yellow crystals from Fr. 2. The ESI-MS (positive) spectrum of PC1 showed a pseudo-molecular ion peak $[\mathrm{M}+\mathrm{H}]^{+}$at $m$ / $z$ 303; this suggested it to have a molecular formula of $\mathrm{C}_{15} \mathrm{H}_{10} \mathrm{O}_{7}$. The 1D-NMR spectrum of PC1 showed five ${ }^{1} \mathrm{H}-\mathrm{NMR}$ peaks, presenting aromatic proton signals in the down-field region and 15 carbon signals with characteristics of a C6-C3-C6 structure in the ${ }^{13} \mathrm{C}-\mathrm{NMR}$ spectrum. By comparison of the 1D-NMR data of PC1 with those in the literature, PC1 was identified as quercetin [15].

Compounds PC2, PC3, PC5 and PC7 were determined from their ${ }^{13} \mathrm{C}-\mathrm{NMR}$ spectra as derivatives of gallic acid with six aromatic carbon signals and a carbonyl group. The molecular weight and formula of PC3 were determined to be 170 and $\mathrm{C}_{7} \mathrm{H}_{6} \mathrm{O}_{5}$, respectively (339.0 [2 M-H $]^{-}$in ESI-MS-negative; $193[\mathrm{M}+\mathrm{Na}]^{+}$in ESI-MS-positive). Compound PC3 was identical to gallic acid on the basis of 1D-NMR data analysis and comparison with those in the literature [16]. Compound PC7 was identified as methyl gallate, which has a molecular formula of $\mathrm{C}_{8} \mathrm{H}_{8} \mathrm{O}_{5}\left(\mathrm{~m} / z 185[\mathrm{M}+\mathrm{H}]^{+}\right.$in ESIMS) and showed patterns of proton and carbon signals similar to those of gallic acid (PC3), with the exception of signals at $3.825 \mathrm{ppm}\left(3 \mathrm{H}, \mathrm{s},-\mathrm{OCH}_{3}\right)$ in ${ }^{1} \mathrm{H}-\mathrm{NMR}$ and $52.250 \mathrm{ppm}\left(-\mathrm{OCH}_{3}\right)$ in ${ }^{13} \mathrm{C}-\mathrm{NMR}$, suggesting a methoxy group. Compound PC2 was identical to protocatechuic acid methyl ester, and was obtained as white crystals. Its molecular formula was deduced to be $\mathrm{C}_{8} \mathrm{H}_{8} \mathrm{O}_{4}$ from a [M$\mathrm{H}]^{-}$pseudo-molecular ion peak at $m / z 167.01$ in ESI-MS. The ${ }^{13} \mathrm{C}-\mathrm{NMR}$ spectrum of PC2 was similar to that of PC7; it also revealed the presence of eight carbon signals, comprising a carbonyl group at $167.07 \mathrm{ppm}$, a methoxy at $51.84 \mathrm{ppm}$ and six aromatic carbons from 115.74 to $150.77 \mathrm{ppm}$ including three methine groups at 115.74, 117.14 and $123.26 \mathrm{ppm}$. In comparison with the ${ }^{1} \mathrm{H}-\mathrm{NMR}$ data of PC7, PC2 revealed a further two aromatic methines. Moreover, the ${ }^{1} \mathrm{H}-\mathrm{NMR}$ spectrum of PC2

Table 1 Antiviral activity of the crude extracts of $P$. chinense against influenza viruses in the CPE reduction assay

\begin{tabular}{|c|c|c|c|c|c|}
\hline \multirow[t]{2}{*}{ Sample } & \multirow[t]{2}{*}{$\mathrm{CC}_{50}^{\mathrm{a}}$} & \multicolumn{3}{|l|}{$\mathrm{EC}_{50}^{\mathrm{b}}\left(\mathrm{S} . \mathrm{I}^{\mathrm{c}}{ }^{\mathrm{c}}\right)$} & \multirow[t]{2}{*}{ Unit } \\
\hline & & $\mathrm{PR}^{\mathrm{d}}$ & $\mathrm{HK}^{\mathrm{e}}$ & $\operatorname{Lee}^{f}$ & \\
\hline $\mathrm{MeOH}$ extract & $>300.0$ & $55.0(>5.5)$ & $38.4(>7.8)$ & $55.5(>5.4)$ & $\mu \mathrm{g} / \mathrm{mL}$ \\
\hline Water layer & $>300.0$ & $175.8(>1.7)$ & $68.5(>4.4)$ & $212.1(>1.4)$ & $\mu \mathrm{g} / \mathrm{mL}$ \\
\hline BuOH layer & $>300.0$ & $45.9(>6.5)$ & $18.3(>16.4)$ & $70.1(>4.3)$ & $\mu \mathrm{g} / \mathrm{mL}$ \\
\hline EtOAc layer & $>300.0$ & $46.9(>6.4)$ & $23.2(>13.0)$ & $50.8(>5.9)$ & $\mu \mathrm{g} / \mathrm{mL}$ \\
\hline OSV-C ${ }^{g}$ & $>100.0$ & $0.38(>263.2)$ & $0.005(>20,000)$ & $1.2(>83.3)$ & $\mu \mathrm{M}$ \\
\hline $\mathrm{RBV}^{h}$ & $>100.0$ & $49.9(>2.0)$ & $20.5(>4.9)$ & $26.6(>3.8)$ & $\mu \mathrm{M}$ \\
\hline
\end{tabular}

${ }^{\mathrm{a}} \mathrm{CC}_{50}, 50 \%$ cell toxicity concentration; ${ }^{\mathrm{b}} \mathrm{EC}_{50}, 50 \%$ effective concentration; ${ }^{\mathrm{c}} \mathrm{S} . \mathrm{I}$, selectivity index $=\mathrm{CC}_{50} / \mathrm{EC}_{50} ;{ }^{\mathrm{d}} \mathrm{PR} 8, \mathrm{~A} / \mathrm{Puerto}$ Rico/8/34 (H1N1); ${ }^{\mathrm{e}} \mathrm{HK}, \mathrm{A} / \mathrm{Hong}$ Kong/8/ 68 (H3N2); ${ }^{\mathrm{f}}$ Lee, B/Lee/40; ${ }^{\mathrm{O}} \mathrm{OSV}-\mathrm{C}$, oseltamivir carboxylate; ${ }^{\mathrm{h}} \mathrm{RBV}$, ribavirin 
<smiles>[R]Oc1c(-c2ccc(O)c(O)c2)oc2cc(O)cc(O)c2c1=O</smiles>

$P C$ 1: $R=H ; P C 4: R=R h a$

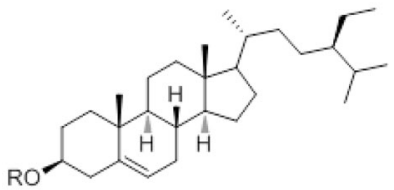

PC 6<smiles>COC(=O)c1ccc(O)c(O)c1</smiles>

PC 2<smiles>O=C(O)c1cc(O)c(O)c(O)c1</smiles><smiles>O=C1OC(=O)c2cc(=O)oc3c(O)c(O)cc1c23</smiles>

PC 3
PC 5<smiles>COC(=O)c1cc(O)c(O)c(O)c1</smiles>

PC 7<smiles>O=C(O)/C=C/c1ccc(O)c(O)c1</smiles>

PC 8

Fig. 1 Chemical structures of substances isolated from P. chinense. PC1: quercetin; PC2: protocatechuic acid methyl ester; PC3: gallic acid; PC4: quercitrin; PC5: ellagic acid; PC6: $\beta$-sitosterol; PC7: methyl gallate; and PC8: caffeic acid

presented three aromatic protons at $7.435(1 \mathrm{H}, \mathrm{dd}, J=2.0$, $8.5 \mathrm{~Hz}, \mathrm{H}-2), 6.893(1 \mathrm{H}, \mathrm{d}, J=8.5 \mathrm{~Hz}, \mathrm{H}-5), 7.493(1 \mathrm{H}, \mathrm{d}$, $J=2.0 \mathrm{~Hz}, \mathrm{H}-6)$, and a methoxy group at $3.801(3 \mathrm{H}, \mathrm{s}$, $-\mathrm{OCH}_{3}$ ), which corresponds to a methyl ester bond based on a cross-peak at $3.801 \mathrm{ppm}$ and $167.07 \mathrm{ppm}$ in HMBC. PC5 was identified as ellagic acid and was obtained as an amorphous solid with the structural formula $\mathrm{C}_{14} \mathrm{H}_{6} \mathrm{O}_{8}$ based on pseudo-molecular ion peaks at $\mathrm{m} / z 325$ $[\mathrm{M}+\mathrm{Na}]^{+}$in ESI-MS (positive mode) and $\mathrm{m} / z 301$ [M$\mathrm{H}]^{-}$in ESI-MS (negative mode). The chemical structure of PC5 was determined by comparison with ${ }^{1} \mathrm{H}$ - and ${ }^{13} \mathrm{C}-$ NMR data published previously [12].

Compound PC8 was purified from Fr. 6 as an amorphous solid. Its chemical structure was identical to that of caffeic acid on the basis of ${ }^{1} \mathrm{H}$ - and ${ }^{13} \mathrm{C}-\mathrm{NMR}$ data analysis and comparison of these data with those in the literature [13]. Compounds PC4 and PC6 were identified by comparing their $R_{f}$ values with those of authentic compounds that were spotted and developed on the same
TLC. PC4 was identified as quercitrin (quercetin 3rhamnoside) and contained a minor gallic acid impurity. Therefore, this compound was not tested in our bioassays. The ${ }^{1} \mathrm{H}$ - and ${ }^{13} \mathrm{C}-\mathrm{NMR}$ spectra of PC6 were compared with those reported previously [14]. Among eight compounds isolated from $P$. chinense, PC6 was identified as $\beta$ sitosterol, while the others were related to flavonoid and phenolic metabolites found commonly in the Polygonaceae family [10, 13, 15]. All PC compounds, except for PC4, have been reported to possess antifungal, antioxidant and other pharmaceutical properties $[13,16]$. In this study, it was aimed to investigate anti-influenza virus activities of the $P$. chinense constituents systematically and their mode-of-action.

\section{Anti-influenza virus activity of isolated compounds}

To study the in vitro anti-influenza virus effects of the isolated substances, CPE inhibition assay was performed (Table 2 and Fig. 2). As reported in previous

Table 2 Antiviral activity of substances isolated from $P$. chinense against influenza viruses in the CPE reduction assay

\begin{tabular}{|c|c|c|c|c|c|c|}
\hline \multirow[t]{2}{*}{ Sample } & \multirow[t]{2}{*}{ Identity } & \multirow[t]{2}{*}{$C C_{50}^{a}$} & \multicolumn{3}{|l|}{$\mathrm{EC}_{50}^{\mathrm{b}}\left(\mathrm{S} . \mathrm{I}^{\mathrm{c}}\right)$} & \multirow[t]{2}{*}{ Unit } \\
\hline & & & $\overline{\mathrm{PR} 8^{\mathrm{d}}}$ & $\mathrm{HK}^{\mathrm{e}}$ & Lee $^{f}$ & \\
\hline$\overline{P C 1}$ & quercetin & $>300.0$ & $12.6(>23.8)$ & $13.1(>22.9)$ & $15.0(>20.0)$ & $\mu \mathrm{g} / \mathrm{mL}$ \\
\hline PC2 & protocatechuic acid methyl ester & 24.1 & $>24.1$ (N.A. $\left.{ }^{9}\right)$ & $>24.1$ (N.A.) & $11.1(2.2)$ & $\mu \mathrm{g} / \mathrm{mL}$ \\
\hline PC3 & gallic acid & 111.1 & $20.8(5.3)$ & $17.5(6.3)$ & $24.5(4.5)$ & $\mu \mathrm{g} / \mathrm{mL}$ \\
\hline PC5 & ellagic acid & $>300.0$ & $81.1(>3.7)$ & $62.4(>4.8)$ & $79.2(>3.8)$ & $\mu \mathrm{g} / \mathrm{mL}$ \\
\hline PC6 & $\beta$-sitosterol & 300.0 & $281.6(1.1)$ & $300.0(1.0)$ & $>300.0$ (N.A.) & $\mu \mathrm{g} / \mathrm{mL}$ \\
\hline PC7 & methyl gallate & $>300.0$ & $18.1(>16.6)$ & $17.1(>17.5)$ & $19.2(>15.6)$ & $\mu \mathrm{g} / \mathrm{mL}$ \\
\hline PC8 & caffeic acid & $>300.0$ & $37.8(>7.9)$ & $32.1(>9.4)$ & $14.7(>20.4)$ & $\mu \mathrm{g} / \mathrm{mL}$ \\
\hline $\mathrm{RBV}^{h}$ & - & $>100.0$ & $21.7(>4.6)$ & $15.5(>6.5)$ & $17.0(>5.9)$ & $\mu \mathrm{M}$ \\
\hline OSV-C ${ }^{\mathrm{i}}$ & - & $>100.0$ & $0.07(>1428)$ & $<0.005(>20,000)$ & $0.21(>476)$ & $\mu \mathrm{M}$ \\
\hline
\end{tabular}

${ }^{a} \mathrm{CC}_{50}, 50 \%$ cell toxicity concentration; ${ }^{\mathrm{b}} \mathrm{EC}_{50}, 50 \%$ effective concentration; ${ }^{\mathrm{C}} \mathrm{S} . \mathrm{l}$, selectivity index $=\mathrm{CC}_{50} / \mathrm{EC}_{50}$; ${ }^{\mathrm{d} P R 8,} \mathrm{~A} / \mathrm{Puerto}$ Rico/8/34 (H1N1); ${ }^{\mathrm{e}} \mathrm{HK}, \mathrm{A} / \mathrm{Hong} \mathrm{Kong} / 8 /$ 68 (H3N2); ; Lee, B/Lee/40; ${ }^{9}$ N.A. not applicable; ${ }^{\text {h } O S V-C ~ o s e l t a m i v i r ~ c a r b o x y l a t e ; ~ i ~} R B V$ ribavirin 

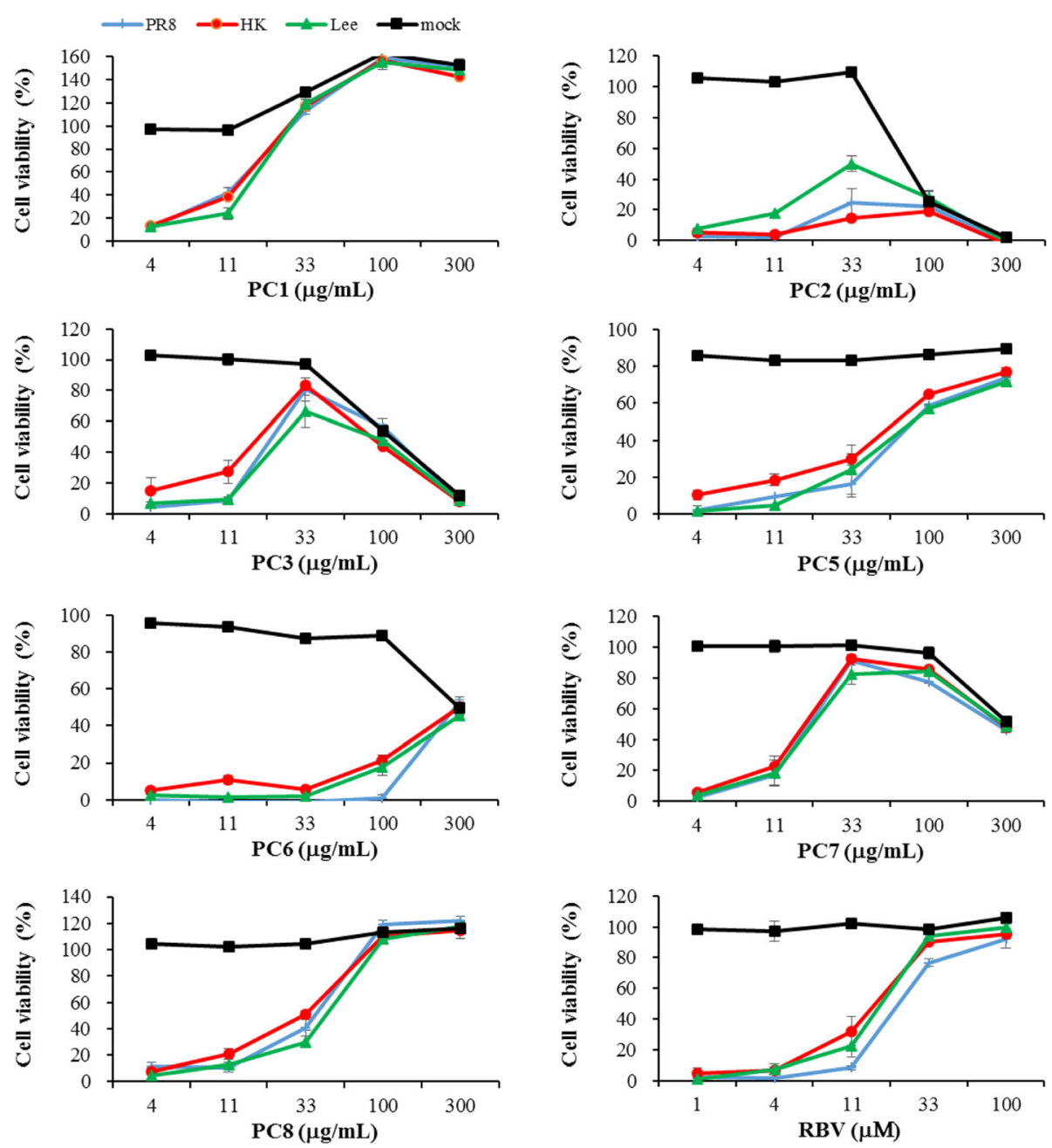

Fig. 2 Dose response curves of PC1 to PC3 and PC5 to PC8 isolated from P. chinense against PR8, HK and Lee and the MDCK host cell line. Cell monolayers were mock-infected or infected with influenza A and B viruses at a $\mathrm{MOI}$ of 0.001 for $1 \mathrm{~h}$. After washing with PBS, compounds serially diluted in MEM with $2 \mathrm{\mu g} / \mathrm{mL}$ TPCK-trypsin were added to the wells and incubated for 3 days. Cell viability was measured by MTT assay. RBV was used as a positive control. The values are means \pm standard deviation (SD) from three replicates

studies [21, 22], PC1 showed anti-influenza A virus activity with an $\mathrm{EC}_{50}$ of $12.6 \mu \mathrm{g} / \mathrm{mL}$ and $13.1 \mu \mathrm{g} / \mathrm{mL}$ for PR8 and HK, respectively, without cytotoxicity at $300 \mu \mathrm{g} / \mathrm{mL}$ (Table 2). This result was in agreement with the report by $\mathrm{Wu}$ et al. [22], in which quercetin revealed broad-spectrum inhibitory activity against influenza A viruses such as PR8, A/FM-1/47/1 (H1N1) and $\mathrm{A} / \mathrm{Aichi} / 2 / 68(\mathrm{H} 3 \mathrm{~N} 2)$ by interaction with the viral HA2 subunit. However, in our study, the compound induced overgrowth of uninfected MDCK cells, resulting in 150-160\% increases in cell viability at 100 and $300 \mu \mathrm{g} / \mathrm{mL}$ (Fig. 2). This undesirably increased optical density was likely not due to the colorimetric properties of PC1, as it was not detected in MTT-based viability tests of other cells, such as Vero (African green monkey kidney cell line), MT4 (human T-cell line) or HuT 78 (human T- cell lymphoma cell line), in the presence of PC1 (data not shown). It was expected that PC1 non-specifically stimulated cell viability of MDCK cells. PC6 displayed marginal or no anti-influenza activity and cytotoxicity to MDCK cells, with a $\mathrm{CC}_{50}$ value of $300 \mu \mathrm{g} / \mathrm{mL}$ (Table 2 and Fig. 2). Accordingly, PC1 and PC6 were excluded from further antiviral assays.

Compounds PC2, PC3, PC5 and PC7 are gallic acid and its derivatives (Fig. 1), all of which, except for PC2, exhibited activity against influenza $A$ and $B$ strains (Table 2). In terms of selectivity, PC7 showed the most desirable antiviral profile with $\mathrm{EC}_{50}$ values of 18.1, 17.1 and $19.2 \mu \mathrm{g} / \mathrm{mL}$ against PR8, HK and Lee, respectively. However, it also contained latent cytotoxicity, reducing cell viability by $49 \%$ at the maximum concentration, $300 \mu \mathrm{g} / \mathrm{mL}$ (Fig. 2). The inhibition of PR8 by PC7 was 
described in a previous report [23]. Nevertheless, it is noteworthy that this may be the first report of the antiinfluenza activity of methyl gallate (PC7) against additional strains $\mathrm{A} / \mathrm{H} 3 \mathrm{~N} 2$ and $\mathrm{B}$. Consistent with other researchers' observation [21, 24], we found that gallic acid (PC3) and ellagic acid (PC5) are active against influenza viruses, even though PC3 showed cytotoxicity with $\mathrm{CC}_{50}$ of $111.1 \mu \mathrm{g} / \mathrm{mL}$ (Table 2). The anti-influenza viral activity of gallic acid and its derivatives as well as quercetin could be associated with their planar structure and cell membrane permeability, as described previously [21]. The last compound, PC8 showed desirable antiviral activity with $\mathrm{EC}_{50}$ values ranging from 14.7 to $37.8 \mu \mathrm{g} / \mathrm{mL}$ without cytotoxicity or an abnormally increase in cell viability at the maximum concentration treated $(300.0 \mu \mathrm{g} / \mathrm{mL})$ (Table 2 and Fig. 2).

The antiviral activity of the three most effective compounds, PC5, PC7 and PC8, was compared by plaque inhibition assay, a standard method for measuring the activity of viral inhibitors. Consistent with results from the CPE assay (Table 2), they inhibited plaque formation of influenza $\mathrm{A}$ and $\mathrm{B}$ viruses in a dose-dependent manner (Fig. 3). Our findings suggest that among the three compounds, PC8 has the greatest antiviral efficacy and lowest cytotoxicity. Even though PC5 suppressed plaque formation significantly at all concentrations tested $(P<0.05)$, it was less potent than PC7 and PC8 (Fig. 3a). PC7 showed potent antiviral activity with relatively high S.I. values (Table 2), but it seemed to have marginal cytotoxicity given that crystal violet staining resulted in faint background images at concentrations higher than $33 \mu \mathrm{g} / \mathrm{mL}$ (Fig. 3b). This observation was in agreement with the CPE assay graph (compare Figs. 2 and 3), confirming the reliability of the cell culturebased antiviral screening system. The antiviral activity of caffeic acid (PC8) against influenza A virus, including $\mathrm{H} 1 \mathrm{~N} 1$ and $\mathrm{H} 3 \mathrm{~N} 2$ strains, was reported previously [25]. Herein, we evaluated the spectrum of its efficacy also against influenza B virus (Fig. 3c).

\section{Mode-of-action of PC5, PC7 and PC8}

Although anti-influenza viral activity of ellagic acid (PC5), methyl gallate (PC7) and caffeic acid (PC8) in vitro or in vivo was presented in several previous reports $[23,25,26]$, their mechanisms of action have not yet been elucidated clearly except for PC8, that targets viral NA protein [27]. To investigate their effects on virus entry and early replication in cells, time-of-addition experiment was performed (Fig. 4). Treatment of PC5 for $2 \mathrm{~h}$ before (pretreatment) or after (post-treatment) reduced viral plaque titers, while plaque reduction was more distinct when it was treated during virus infection (co-treatment) (Fig. 4a). It means that PC5 could affect both viral and cellular factors working at early steps of the virus life cycle and potentially interfere with their interaction. PC7 also showed the most significant antiviral activity when it was co-treated, resulting in about 35\% reduction (Fig. 4b). It marginally reduced the viral infectivity by $15 \%$ at the
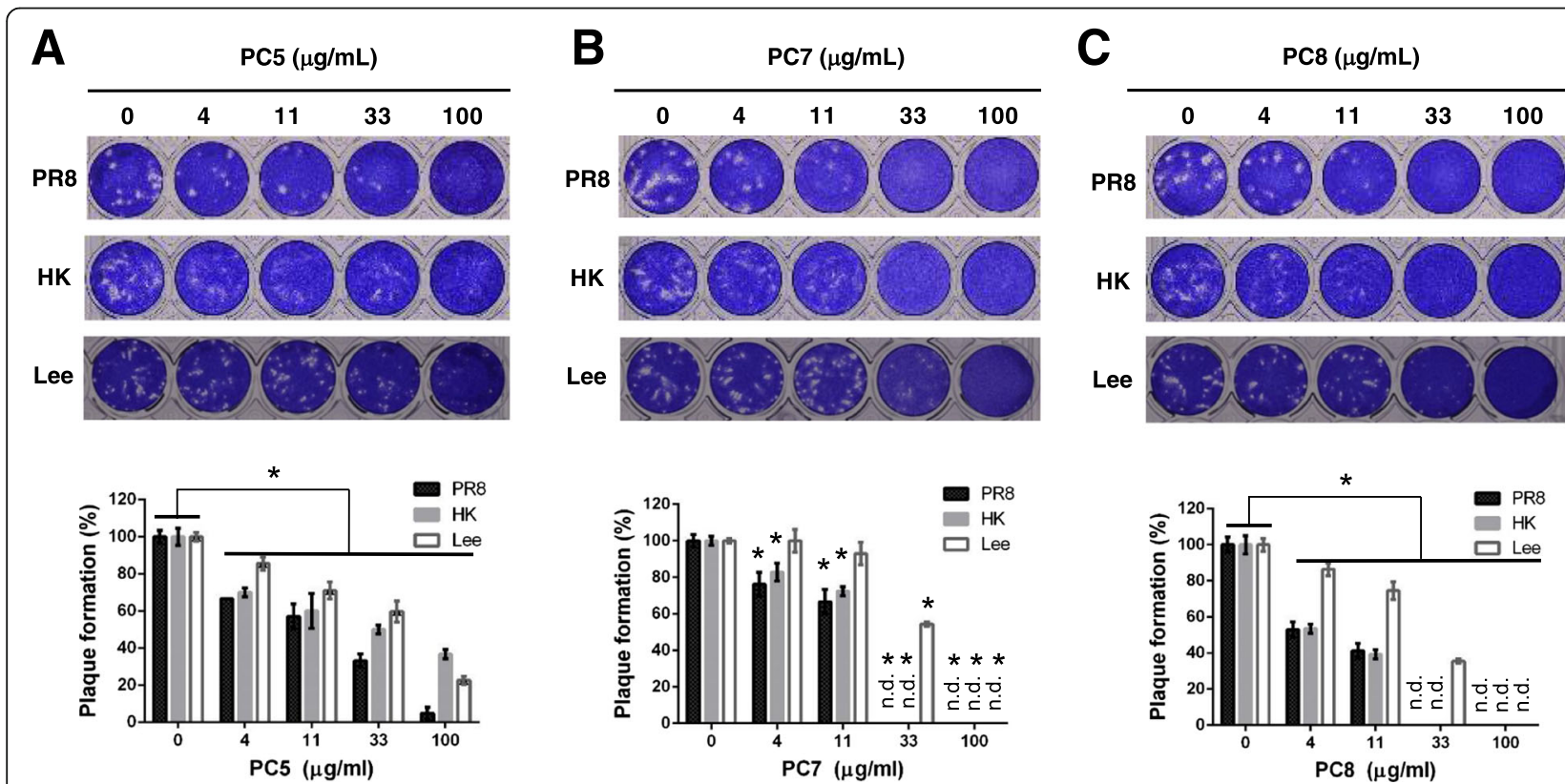

Fig. 3 Plaque inhibition assay of PC5 (a), PC7 (b) and PC8 (c) against PR8, HK and Lee. At $1 \mathrm{~h}$ after infection with influenza virus at an MOI of 0.001, MDCK cells were treated with serially diluted compounds dissolved in the overlay medium. At day 3 postinfection, viral plaques were visualized using crystal violet staining. The images are representative of three experiments (upper). The numbers of plaques in each well were counted (lower). Shown are averaged percentages and SD of three different wells. n.d., not detected. ${ }^{*} P<0.05$ 


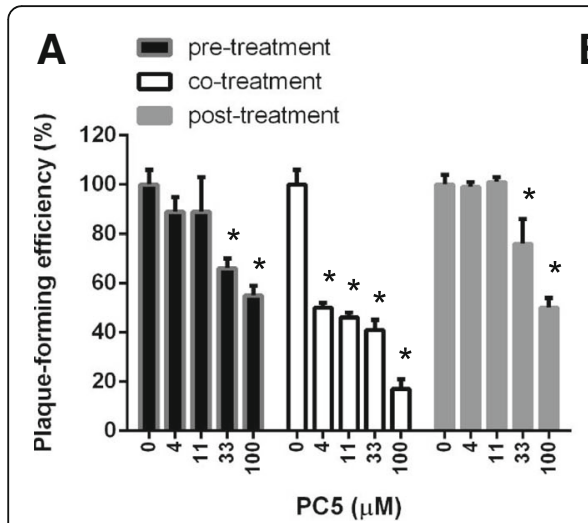

B

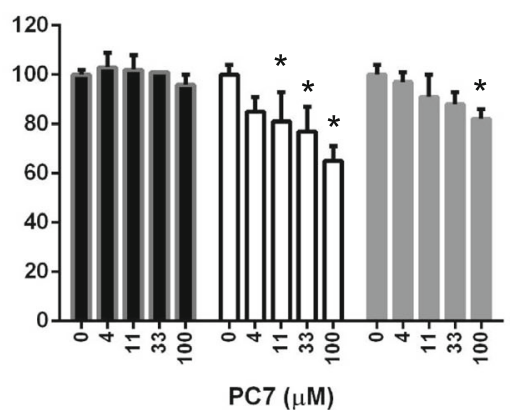

C

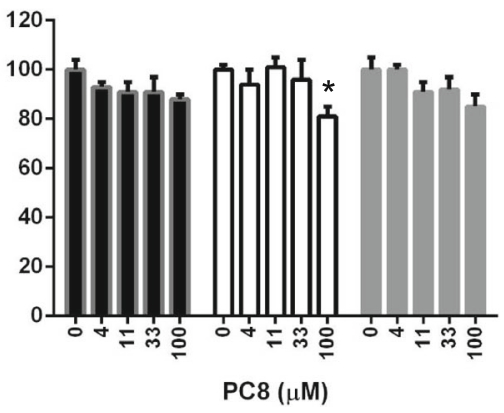

Fig. 4 Time-of-addition of the PC compounds. Mock (0.1\% DMSO) or increasing concentrations of PC5 (a), PC7 (b) or PC8 (c) were applied to MDCK cells for $2 \mathrm{~h}$ before (pre-treatment), during (co-treatment) or after (post-treatment) PR8 infection (40 PFU per well in 48 -well plates) at $37^{\circ} \mathrm{C}$. Cells were washed with PBS and additionally incubated under the overlay medium for 3 days at $33^{\circ} \mathrm{C}$. The number of plaques was counted after staining with crystal violet. The values shown are the means \pm S.D. of triplicate samples and expressed as a percentage relative to the plaque number with mock solution in each experiment. ${ }^{*} P<0.05$

maximum concentration $(100 \mu \mathrm{M})$ in the post-treatment experiment, while no inhibition when treated before virus infection. It is expected that PC7 might regulate a host factor essential for influenza virus entry or early replication. PC8 resulted in no significant antiviral activity when treated before or after virus infection, but its co-treatment barely showed the efficacy at the maximum concentration (Fig. 4c). It can be suggested that PC8 is partially involved in suppression of the influenza virus entry step. To ensure that PC5 and PC7 suppress influenza virus entry or early replication, we analyzed viral NP protein production in cells by confocal microscopy (Fig. 5). Here, the 4-h incubation of influenza A virus PR8 was optimized for nuclear localization of NP. The result clearly showed that both PC5 and PC7 inhibit the early steps similar to EGCG, which is a virus entry blocker [20]. As expected, PC8 did not affect NP signal intensity or its localization within $4 \mathrm{~h}$ after virus infection.

To further examine whether PC8, known as an NA inhibitor [27], targets not only wild-type NA protein but also its OSV-C-resistant one, fluorescence NA inhibition assay was performed using live influenza viruses, PR8 and rgPR8(H275Y) (Fig. 6). Although NA inhibitory effect of PC8 against PR8 was less potent than that of OSV-C, it showed consistent activity against $\operatorname{rgPR} 8(\mathrm{H} 275 \mathrm{Y})$, that is a reverse genetically rescued virus resistant to OSV-C (compare panels A and B in Fig. 6). It suggested that PC8 targets influenza virus NA protein as OSV-C does but in a different binding manner. Moreover, previous reports proposed that the NA activity is involved in influenza virus entry as well as release of progeny virus [28]. Thus, it can be explained the reason for marginal inhibition of the initial stage of PR8 infection by the NA inhibitor, PC8 (Fig. 4c).

\section{Conclusion}

The present study is the first report on anti-influenza virus activity of $P$. chinense and identification of the active components. $\mathrm{MeOH}$ extract, EtOAc and $\mathrm{BuOH}$ layers of the plant were active against influenza viruses
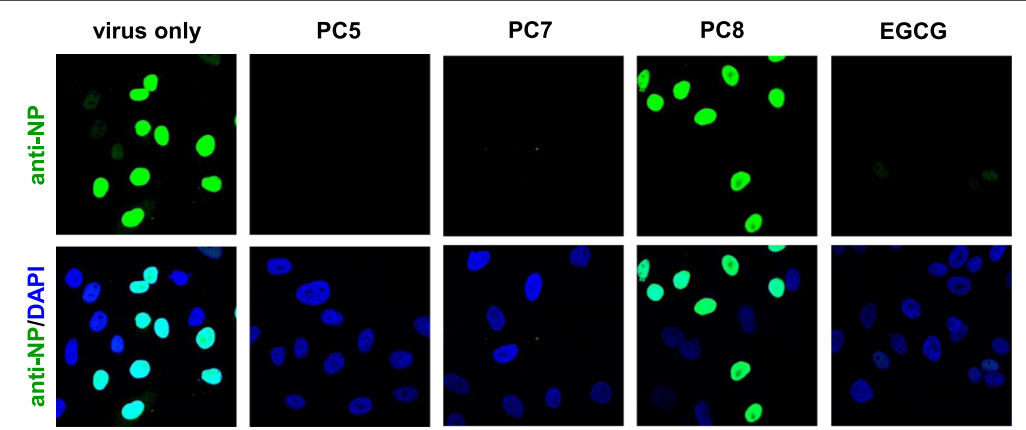

Fig. 5 Confocal microscopy. MDCK cells were infected with PR8 virus at an $\mathrm{MOI}$ of 1 in the presence either of 1 mM PC5, PC7 or PC8 or of 10 MM EGCG (an entry blocker) at $37^{\circ} \mathrm{C}$ for $4 \mathrm{~h}$. The viral NP was labeled with mouse anti-NP antibody and Alexa Fluor $488-\mathrm{conjugated}$ goat antimouse antibody (green). Cellular nuclei were counterstained with DAPI (blue). Original magnification, $400 \times$ 


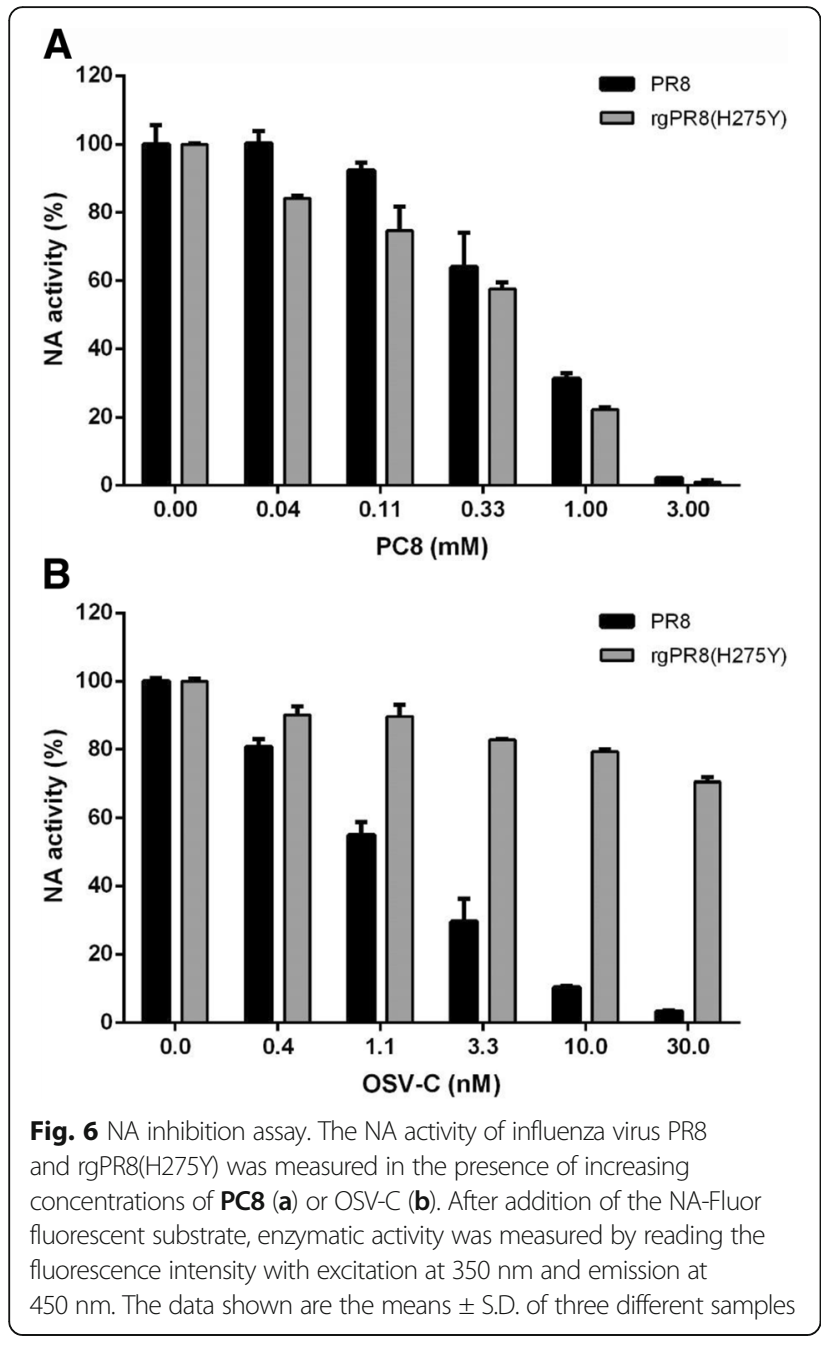

of $\mathrm{A} / \mathrm{H} 1 \mathrm{~N} 1, \mathrm{~A} / \mathrm{H} 3 \mathrm{~N} 2$ and $\mathrm{B}$. Among constituents isolated from the EtOAc layer, ellagic acid, methyl gallate and caffeic acid exhibited considerable inhibitory activity against the pathogens. Based on the mode-of-action studies, ellagic acid and methyl gallate suppress the early steps of the viral life cycle. In contrast caffeic acid targets the NA protein, comparably suppressing both wild-type and OSV-C-resistant influenza viruses. Our study suggests that the multi-functional botanical materials of $P$. chinense could be promising inhibitors of influenza A and B viruses and applied to development of a novel herbal medicine.

\footnotetext{
Abbreviations

$\mathrm{BuOH}$ : Butanol; $\mathrm{CC}_{50}$ : The half maximal cytotoxic concentration;

CMC: Carboxymethylcellulose; CPE: Cytopathic effect; $\mathrm{EC}_{50}$ : The half maximal effective concentration; ESI-MS: Electrospray ionization-mass spectroscopy; EtOAc: Ethyl acetate; FBS: Fetal bovine serum; HA: Hemagglutinin; HK: Virus strain A/Hong Kong/8/68 (H3N2); Lee: Virus strain B/Lee/40; M2: Matrix protein 2; MDCK: Madin-Darby canine kidney; MEM: Minimum essential medium; MeOH: Methanol; MOI: Multiplicity of infection; MTT: 3-(4,5dimethylthiazol-2-yl)-2,5-diphenyltetrazolium bromide; NA: Neuraminidase; NMR: Nuclear magnetic resonance; OSV-C: Oseltamivir carboxylate; PR8: Virus strain A/Puerto Rico/8/34 (H1N1); RBV: Ribavirin; S.I.: Selectivity index; TLC: Thin-layer chromatography
}

\section{Acknowledgements}

The authors would like to acknowledge National Key Laboratory for Petrochemical and Refinery Technologies and Prof. Chuc Ngoc Mai, Vietnam Institute of Industrial Chemistry for the great general support and encouragement. The authors thank Prof. Hoang Dinh Vu and Dr. Cuong Tu Ho for their assistance in reviewing the manuscript and their constructive comments.

\section{Funding}

This work was funded in part by project number CNHD.ĐT.048/13-15 from the Ministry of Industry and Trade, Vietnam. This work was supported by the Transgovernmental Enterprise for Pandemic Influenza in Korea (TEPIK) (Grant A103001 for M. Kim).

\section{Availability of data and materials}

All the data are contained within the manuscript.

\section{Authors' contributions}

TIT, HTN, HWP and QLD performed experiments of isolation and identification of isolated compounds. MK, HYL and YJ performed experiments of antiviral tests and analyzed the data. HTN and TNN participated in sampling and generation of extraction. QLD, MK and JCK designed the study and wrote the manuscript. All authors read and approved the final manuscript.

\section{Competing interests}

The authors declare that they have no competing interests.

\section{Consent for publication}

Not applicable.

\section{Ethics approval and consent to participate} Not applicable.

\section{Publisher's Note}

Springer Nature remains neutral with regard to jurisdictional claims in published maps and institutional affiliations.

\section{Author details}

${ }^{1}$ R\&D Center of Bioactive Compounds, Vietnam Institute of Industrial Chemistry, 2nd Pham Ngu Lao, Hoan Kiem, Hanoi 10 000, Vietnam. ${ }^{2}$ Center for Virus Research and Testing, Korea Research Institute of Chemical Technology, Gajeong-ro, Yuseong, Daejeon 34114, Republic of Korea. ${ }^{3}$ Department of Agricultural Chemistry, Institute of Environmentally Friendly Agriculture, College of Agriculture and Life Sciences, Chonnam National University, 77 Yongbong-Ro, Buk-Gu, Gwangju 500-757, Republic of Korea. ${ }^{4}$ Department of Phytochemistry, Vietnam Institute of Industrial Chemistry, 2nd Pham Ngu Lao, Hoan Kiem, Hanoi, Vietnam. ${ }^{5}$ World Institute of Kimchi, an Annex of Korea Food Research Institute, Gwangju 61755, Republic of Korea.

Received: 6 January 2017 Accepted: 10 March 2017 Published online: 21 March 2017

\section{References}

1. Palese P, Shaw ML. Orthomyxoviridae: the viruses and their replication. In: Knipe DM, Howley PM, Griffin DE, Lamb RA, Martin MA, Roizman B, Straus SE, editors. Fields virology. 5th ed. Philadelphia: Lippincott Williams and Wilkins; 2007. p. 1647-89.

2. Fujiyoshi Y, Kume NP, Sakata K, Sato SB. Fine structure of influenza a virus observed by electron cryo-microscopy. EMBO J. 1994;13(2):318-26.

3. Barik S. New treatments for influenza. BMC Med. 2012;10(1):1-15.

4. Kiyohara H, Ichino C, Kawamura Y, Nagai T, Sato N, Yamada H. Patchouli alcohol: in vitro direct anti-influenza virus sesquiterpene in Pogostemon cablin Benth. J Nat Med. 2012;66:55-61.

5. Regoes RR, Bonhoeffer S. Emergence of drug-resistant influenza virus: population dynamical considerations. Science. 2006;312(5772):389-91.

6. Hwang BS, Lee IK, Choi HJ, Yun BS. Anti-influenza activities of polyphenols from the medicinal mushroom Phellinus baumii. Bioorg Med Chem Lett. 2015;25(16):3256-60.

7. Pham HH. An illustrated flora of Vietnam, vol. I. Vietnam: Tre Publishing House, Hochiminh City; 2000. p. 747 
8. Srividya AR, Shalom A, Chandrasekhar R, Vijayan P, Vishnuvarthtan VJ. Cytotoxic, antioxidant and antimicrobial activity of Polygonum chinensis Linn. Int J Pharm Sci Nanotech. 2012;4:1569-74.

9. Tsai PL, Wang JP, Chang CW, Kuo SC, Vhao PD. Constituents and bioactive principles of Polygonum chinensis. Phytochemistry. 1998;49:1663-6.

10. Ezhilan B, Neelamegam R. GC-MS analysis of phytocomponents in the ethanol extract of Polygonum chinense L. Pharm Res. 2012;4:11-4.

11. Ismail IF, Golbabapour S, Hassandarvish P, Hajrezaie M, Abdul Majid N, Kadir FA, Al-Bayaty F, Awang K, Hazni H, Abdulla MA. Gastroprotective activity of Polygonum chinense aqueous leaf extract on ethanol-induced hemorrhagic mucosal lesions in rats. Evid Based Complement Alternat Med. 2012;2012: 404012.

12. Thuan DNT, Phan TNH, Duc HT, Trung ND. Bio-activities of the methanol extracts from some species belonging to the genus Polygonum in lam dong province. Vietnam J Biol. 2012:31(2):43-6.

13. Xiao HT, Tsang SW, Qin HY, Choi FFK, Yang ZJ, Han QB, Chen HB, Xu HX, Shen H, Lu AP. A bioactivity-guided study on the anti-diarrheal activity of Polygonum chinense Linn. J Ethnopharmacol. 2013;149:499-505.

14. Zhang X, Geoffroy P, Miesch M, Julien-David D, Raul F, Aoudé-Werner D, Marchioni E. Gram-scale chromatographic purification of $\beta$-sitosterol: synthesis and characterization of $\beta$-sitosterol oxides. Steroids. 2005;70(13): 886-95.

15. Azimova SS, Vinogradova VI. Quercetin (3,5,7,3',4'-Pentahydroxyflavone). In: Azimova SS, Vinogradova VI, editors. Natural compounds: flavonoids. New York: Springer New York; 2013. p. 98-9.

16. Nguyen DMC, Seo DJ, Lee HB, Kim IS, Kim KY, Park RD, Jung WJ. Antifungal activity of gallic acid purified from Terminalia nigrovenulosa bark against Fusarium solani. Microb Pathog. 2013;56:8-15.

17. Hoffmann E, Neumann G, Kawaoka Y, Hobom G, Webster RG. A DNA transfection system for generation of influenza a virus from eight plasmids. Proc Natl Acad Sci U S A. 2000;97(11):6108-13.

18. Hoffmann E, Stech J, Guan Y, Webster RG, Perez DR. Universal primer set for the full-length amplification of all influenza a viruses. Arch Virol. 2001; 146(12):2275-89.

19. Kim M, Kim SY, Lee HW, Shin JS, Kim P, Jung YS, Jeong HS, Hyun JK, Lee CK. Inhibition of influenza virus internalization by (-)-epigallocatechin-3-gallate. Antivir Res. 2013:100:460-72.

20. Jang YJ, Achary R, Lee HW, Lee HJ, Lee CK, Han SB, Jung YS, Kang NS, Kim P, Kim M. Synthesis and anti-influenza virus activity of 4-oxo- or thioxo-4,5dihydrofuro[3,4-c]pyridin-3(1H)-ones. Antivir Res. 2014;107:66-75.

21. Kaihatsu K, Kawakami C, Kato N. Potential anti-influenza virus agents based on coffee ingredients and natural flavonols. Nat Prod Chem Res. 2014;2:129. doi:10.4172/2329-6836.1000129.

22. Wu W, Li R, Li X, He J, Jiang S, Liu S, Yang J. Quercetin as an antiviral agent inhibits influenza a virus (IAV) entry. Viruses. 2016;8(1):6. doi:10.3390/ v8010006

23. Kane CJM, Menna JH, Sung CC, Yeh YC. Methyl gallate, methyl-3,4,5trihydroxybenzoate, is a potent and highly specific inhibitor of herpes simplex virus in vitro. II. Antiviral activity of methyl gallate and its derivatives. Biosci Rep. 1988;8(1):95-102.

24. Chen GH, Lin YL, Hsu WL, Hsieh SK, Tzen JTC. Significant elevation of antiviral activity of strictinin from Pu'er tea after thermal degradation to ellagic acid and gallic acid. J Food Drug Anal. 2015;23(1):116-23.

25. Utsunomiya H, Ichinose M, Ikeda K, Uozaki M, Morishita J, Kuwahara T, Koyama AH, Yamasaki H. Inhibition by caffeic acid of the influenza a virus multiplication in vitro. Int J Mol Med. 2014;34(4):1020-4.

26. Park S, Kim Jl, Lee I, Lee S, Hwang MW, Bae JY, Heo J, Kim D, Han SZ, Park MS. Aronia melanocarpa And its components demonstrate antiviral activity against influenza viruses. Biochem Biophys Res Commun. 2013;440(1):14-9.

27. Xie Y, Huang B, Yu K, Shi F, Liu T, Xu W. Caffeic acid derivatives: a new type of influenza neuraminidase inhibitors. Bioorg Med Chem Lett. 2013;23(12): 3556-60.

28. Ohuchi M, Asaoka N, Sakai T, Ohuchi R. Roles of neuraminidase in the initial stage of influenza virus infection. Microbes Infect. 2006;8:1287-93.

\section{Submit your next manuscript to BioMed Central and we will help you at every step:}

- We accept pre-submission inquiries

- Our selector tool helps you to find the most relevant journal

- We provide round the clock customer support

- Convenient online submission

- Thorough peer review

- Inclusion in PubMed and all major indexing services

- Maximum visibility for your research

Submit your manuscript at www.biomedcentral.com/submit
Biomed Central 